\title{
PENGEMBANGAN MODUL PENDIDIKAN AGAMA ISLAM BERBASIS MULTIKULTURAL DI SMA
}

\author{
Syamsuhari ${ }^{1}$, Naswan Suharsono ${ }^{2}$, Made Tegeh ${ }^{3}$ \\ 1,2,3Program Studi Management Pendidikan, Program Pascasarjana \\ Universitas Pendidikan Ganesha \\ Singaraja, Indonesia
}

e-mail: \{syamsuhari, naswan.suharsono, made.tegeh\}@pasca.undiksha.ac.id

\begin{abstract}
Abstrak
Penelitian pengembangan ini bertujuan menghasilkan produk berupa modul pendidikan agama islam berbasis multikultural untuk siswa kelas $X$ di SMA yang sudah teruji kelayakannya untuk memasukan nilai-nilai multikultural pada setiap pokok bahasannya.

Modul ini dikembangkan dengan mengadaptasi model pengembangan Dick dan Carey, dengan langkahlangkah pengembangannya yaitu, menganalisis kebutuhan untuk mengidentifikasi tujuan, menganalisis pembelajaran, menganalisis pembelajaran dan konteknya, menuliskan tujuan untuk kerja, mengembangkan instrumen penilaian, mengembangkan strategi pembelajaran, mengembangkan dan memilih bahan pembelajaran, merancang dan melaksanakan Evaluasi Formatif dan merevisi pembelajaran. Validasi draf mencakup (1) uji ahli isi; (2) uji ahli media; (3) uji ahli desain pembelajaran; (4) uji siswa perorangan; (5) uji kelompok kecil; dan (6) uji lapangan.

Hasil review uji ahli isi, ahli media dan ahli desain menyatakan bahwa modul pendidikan agama islam berbasis multikultural yang dikembangkan sudah layak. Prosentase keseluruhan subyek pada ahli isi dan ahli desain terletak pada kategori sangat baik, sedangkan ahli media memberikan tanggapan disetiap subyeknya adalah kesesuaian antara gambar dengan sasaran yang ada disetiap modulnya. Hasil prosentase keseluruhan subyek pada uji perorangan yaitu sebesar terletak pada kualifikasi baik dengan jumlah siswa 3 orang. Hasil prosentase keseluruhan subyek pada uji kelompok kecil yaitu sebesar dengan kualifikasi baik dengan jumlah siswa 9 orang. Hasil prosentase keseluruhan subyek pada uji lapangan untuk pendidik dengan kualifikasi sangat baik. Hasil prosentase keseluruhan subyek pada peserta didik dalam uji lapangan yaitu dengan kualifikasi baik dengan jumlah siswa 13 orang.
\end{abstract}

Kata kunci: pengembangan, Dick dan Carey,multikultural

\begin{abstract}
This delopment research is aimed to produce a product of multiculture based of islam education module for $\mathrm{X}$ grade of SMA students, of which proper has been evaluated to insert the multicultural values in each subtitle of islamic education.

The module is developed by adapting Dick and Carey developing model with the following steps: analysing requirements to identify the goals

(instructional goals), analysing the learning process, analysing the learning process and its contexts, writing the goals of performance, developing evaluation instruments, developing teaching strategy, developing and selecting teaching materials, constructing and conducting formative evaluation, revising the learning process. Draft validation involves (1) Judge of content expert (2) Judge of media expert (3) Judge of teaching design (4) Test of students individually (5) Test of small groups and test of field.

The result of expert content judge, media expert and design expert stated that the multiculture based module is already proper. Percentage of the whole subject of design and content experts is $91,67 \%$ and $90,63 \%$ catagorized as good furthermore media expert responded that in each module pictures and targets are already appropriate. Percentage of the whole subjects on individual test that is $89,55 \%$ and qualified as good. Percentage of the whole subjects on test of small groups is $87,53 \%$ and qualified as good. Percentage of subjects on field test is $90,13 \%$, qualified good. Percentage of the whole subjects on filed test is $88,07 \%$ and qualified good.
\end{abstract}

Keywords : developing, dick and carey, multicultural 


\section{PENDAHULUAN}

Pendidikan multikultural merupakan bagian dari akhlak yang tidak bisa dipisahkan dari pendidikan agama yang dapat di jadikan sebagai penguat dalam mewujudkan keutuhan Negara Kesatuan Republik Indonesia, kondisi dilapangan menggambarkan bahwa Indonesia, mengandung potensi konflik yang dapat mengganggu stabilitas pembangunan bangsa. Oleh karena itu, pendidikan multikultural sangat penting untuk dimasukkan dalam setiap proses pembelajaran pada lembaga-lembaga pendidikan, khususnya dalam hal ini pembelajaran di Sekolah Menengah Atas (SMA).

Pada umumnya SMA merupakan sekolah formal yang mampu menampung atau memiliki banyak siswa yang terdiri dari berbagai suku bangsa, ras, etnis, budaya, kepercayaan dan agama. Sangat menarik mengungkap tentang adanya keberagaman budaya karena dalam perjalanannya banyak sekali terjadi penyaluran budaya melalaui materi pembelajaran di sekolah. Disamping itu adanya perbedaan agama, juga mejadikan lingkungan sekolah menjadi lebih beragam. Lembaga pendidikan sebagai sebuah pranata sosial merupakan tempat untuk pengembangan interaksi antar pendidik dan peserta didik untuk mewujudkan suatu sistem norma. Disinilah pentingnya lembaga pendidikan mengembangkan budaya yang sesuai dengan tatanan moral yang ideal dalam proses pendidikannya, yang pada akhirnya dapat dikembangkan dan diaplikasikan dalam lingkup masyarakat yang sesungguhnya.

Sebagai dasar pendidikan multikultural dilndonesia terdapat dalam UU Nomor 20 Tahun 2003 tentang Sistem Pendidikan Nasional. Selain UU tentang Sisdiknas ini, sebagai bukti dalam Kurikulum 2013 pada KI1 adanya konsep pengakuan menjalankan ajaran agama yang dianut. Dalam KI2 mengusung konsep menghargai perbedaan dan saling bekerja sama dan pada KI4 adanya pengakuan adanya perbedaan kemampuan setiap peserta didik.
Penyelenggaraan Pendidikan Agama Islam (PAI) pada sekolah merupakan amanat Undang-undang Nomor 20 tahun 2003 tentang Sistem Pendidikan Nasional. Hal ini secara jelas dinyatakan bahwa tujuan pendidikan nasional adalah untuk berkembangnya potensi peserta didik agar menjadi manusia yang beriman dan bertakwa kepada Tuhan Yang Maha Esa, berakhlak mulia, sehat, berilmu, cakap, kreatif, mandiri, dan menjadi warga negara yang demokratis serta bertanggung jawab.

Berdasar pada tujuan UU. No.20 th.2003 tersebut bahwa Pendidikan Agama Islam juga sebagai rancangan dan penunjang untuk mencapai Pendidikan Nasional karena merupakan salah satu pendidikan yang mendukung tujuan Pendidikan Nasional. Untuk mengajarkan pendidikan norma yang langsung bersumber pada norma yang ada.

Maka Pendidikan Agama Islam memiliki posisi yang penting dalam sistem pendidikan nasional, pendidikan agama Islam sering disebut sebagai pendidikan akhlak bangsa. Karena merupakan salah satu komponen strategis dalam kurikulum pendidikan nasional yang bertanggung jawab terhadap pembinaan watak dan kepribadian bangsa Indonesia dan tergolong dalam muatan wajib kurikulum.

Pelajaran Pendidikan Agama Islam memerlukan keahlian khusus dalam mengelola proses pembelajaran, terutama seorang guru harus memiliki kemampuan dalam memanfaatkan media pembelajaran, pada kenyataannya seorang guru sangat sedikit yang mampu mengembangkan dan membuat bahan ajar, masih banyak seorang guru yang bergantung pada LKS. Padahal pada buku LKS kurang efektif dan belum mampu membantu proses belajar beragama peserta didik dalam mengembangkan kompetensi, seperti membangun kompetensi beragama yaitu keutuhan beragama, sikap dan membiasakan mengamalkan nilai ajaran agama/perilaku

Alokasi waktu jam mengajar hanya tiga jam untuk satu minggu, orang tua atau masyarakat pada umumnya berharap terhadap Pendidikan Agama Islam yang 
diberikan akan mampu membentuk generasi yang taqwa serta secara aktif mampu membentengi diri mereka sendiri dari segala pengaruh yang tidak baik, terutama dari lingkungan di mana mereka berada.

Harapan ini sesuai dengan tujuan pendidikan agama Islam adalah sebagai upaya sadar dan terencana dalam menyiapkan peserta didik untuk mengenal, memahami, menghayati hingga mengimani, bertaqwa, dan berakhlak mulia dalam mengamalkan ajaran agama Islam dari sumber utama kitab suci al-Qur'an dan alhadits, melalui kegiatan bimbingan, pengajaran, latihan, serta penggunaan pengalaman. Diikuti tuntunan untuk menghargai penganut agama lain dalam hubungannya dengan kerukunan antarumat berbagama dalam masyarakat hingga terwujud kesatuan dan persatuan bangsa.

Mata pelajaran PAI di sekolah secara keseluruhan merupakan satu kesatuan yang bulat dan utuh. Hal ini dimaksudkan agar dapat menghasilkan peserta didik yang memiliki kepribadian utuh dan terintegrasi, serta jangan sampai menjadi pribadi yang terpecah-belah. PAI yang utuh dan bulat itu meliputi al-Qur'an/al-Hadits, keimanan, akhlak, fiqh/ibadah, dan tarikh. Ini sekaligus menggambarkan bahwa ruang lingkup PAI mencakup perwujudan keserasian, keselarasan, dan keseimbangan hubungan manusia dengan Allah SWT, dengan diri sendiri, sesama, makhluk lainnya, dan alam lingkungannya.

Karangasem adalah kota sederhana perkembangan dalam struktur sosial yang tidak hanya mempunyai penduduk lokal. Tetapi memiliki masyarakan yang multikultural, karena banyak sekali pendatang, baik dari kalangan siswa dan siswi yang bersekolah di sekolah menengah lanjutan pertama. Melihat adanya perbedaan kultur dalam masyarakat dengan berbagai agama yang berbeda (Kristen, Katolik, Protestan dan Kong $\mathrm{Hu} \mathrm{Cu}$ Cina) ini, maka kota karangasem rawan akan terjadinya perseteruan, karena perbedaan kultural masyarakat tersebut. Untuk membina kerukunan antar perbedaan kultur dalam masyarakat setempat (mengingat adanya perbedaan kultur), maka diperlukan adanya satu kesepemahaman tentang nilai-nilai multikultural yang terbina dilingkungan sekolah, agar tercipta masyarakat yang saling menghormati, menghargai, memahami dan tolong menolong.

SMA Negeri 2 Amlapura sebagai salah satu sekolah favorit dan berprestasi akademik, non akademik, didalamnya terdapat keberagaman dan sangat heterogen. Selama ini sekolah tersebut aman-aman saja tidak ada problem etnis, proses belajar mengajarpun berjalan lancar. Pelaksanaan multikultural berjalan sesuai ajaran dan keyakinan agamanya, namun secara tertulis penanaman nilai-nilai mulktikultural belum terakomodir dalam mata pelajaran.

Melalui pembelajaran Pendidikan Agama Islam dan pembelajaran secara intrakurikuler maupun ekstrakurikuler. Maka salah satu strategi guru pendidikan Agama Islam menanamkan nilai-nilai multikultural melalui modul pendidikan Agama Islam yang berbasis Multikultural agar siswa mampu belajar hidup dalam perbedaan, membangun saling percaya memelihara, saling pengertian, menjunjung sikap saling menghargai terbuka dalam berpikir.

SMA Negeri 2 Amlapura yang letaknya cukup strategis karena berada ditengah-tengah kota karangasem. Posisi sekolah yang berada di jantung perkotaan, sangat perlu adanya pengembangan program-program keagamaan dalam mengimbangi akan rawannya pengaruh negatif yang berdampak kehancuran moral, maka lembaga sekolah sangat perperan penting sebagai proses penyadaran diri siswa siswi.

Berkaitan dengan masalah ini, merupakan sebuah tantangan dan pengalaman bagi guru pendidikan Agama Islam SMA Negeri 2 Amlapura dalam menumbuhkan nilai-nilai multikultural, semangat toleransi kebersamaan, dan persudaraan sehingga mampu menerapkan nilai multikultural di lembaga pendidikan sekolah tersebut. Karena keragaman yang ada dengan sikap tetap menghargai dan menghormati inilah yang menjadi ketertarikan peneliti. 
Melihat kondisi tersebut, penulis berusaha melakukan inovasi dalam penyampaikan materi Pendidikan pendidikan Agama Islam di SMA Negeri 2 Amlapura berbasis multikultural melaluli modul Pendidikan Agama Islam. Diharapkan melalui modul yang penulis rancang, motivasi belajar siswa akan meningkat, berkesan, bermakna, dan memperoleh hasil belajar yang optimal, karena dalam suasana pembelajaran, siswa dapat belajar lebih senang, tanpa rasa terbebani dan guru juga dapat menyesuaikan dengan tujuan yang ingin dicapai.

Oleh karena itu dilakukan perubahan dengan mengembangkan modul, dengan harapan nilai-nilai multikultikultural dapat ditingkatkan. Dan hasil yang diperoleh anak didik semakin baik dibandingkan dengan metode sebelumnya. Hal inilah yang melatar belakangi penulis berkeinginan mengembangkan dan menyusun bahan ajar modul untuk meningkatkan nilai-nilai multikultural dalam Pendidikan Agama Islam pada siswa SMA Negeri 2 Amlapura

Pengembangan bahan ajar modul pembelajaran pendidikan Agama Islam di SMA berbasis multikultural akan dikembangkan di SMA Negeri 2 Amlapura. Lembaga ini peneliti anggap cocok, mengingat selama ini peneliti mengajar di lembaga ini. Peneliti merasakan bahwa SMA Negeri 2 Amlapura memberikan perhatian yang besar terhadap perkembangan Pendidikan Agama termasuk Pendidikan Agama Islam, ini sebagai bentuk wujud toleransi terhadap agama lain dalam mewujudkan nilai-nilai multikultur di SMA Negeri 2 Amlapura, Kepala Sekolah memberikan apresiasi terhadap pembelajaran agama Islam ini bisa dilihat dari segi penyediaan sarana prasarana, sekolah telah memberikan tempat ibadah, di tambah dengan perlengkapan ibadah yang diperoleh dari bantuan sarana ibadah Departemen Agama seperti karpet, mukena, sarung, peci dan buku-buku agama Islam. Selama ini pelaksanaan pendidikan multikultural di SMA Negeri 2 dapat dilihat pada setiap pagi, melalui pelaksanaan do'a sebelum masuk kelas dilaksanakan sesuai dengan agama masing-masing, selain itu juga setiap tahun dilaksanakan acara halal bihalal dan buka puasa bersama disekolah. yang dihadiri oleh masing-masing agama.

Belajar adalah suatu perubahan perilaku yang relatif dan permanen dan dihasilkan dari pengalaman masa lalu ataupun pembelajaran yang bertujuan atau direncanakan. Menurut Eveline dan Nara (2010), belajar adalah proses yang komplek yang didalamnya terkandung dalam beberapa aspek. Aspek tersebut meliputi: a) bertambahnya jumlah pengetahuan, b) adanya kemampuan mengingat dan memproduksi,c) adanya penerapan pengetahuan, d) menyimpulkan makna, e) menafsirkan dan mengaktifkan dengan realitas. (Sumantri. 2015: 2)

Pembelajaran merupakan salah satu sub dari sistem pendidikan, disamping kurikulum, konseling, administrasi, dan evaluasi (Reigelut, 1999:6). Sedangkan menurut (Miarso, 2004:545) pembelajaran adalah suatu usaha yang disengaja, bertujuan, dan terkendali agar orang lain belajar atau terjadi perubahan yang relatif menetap pada diri orang lain. Dapat pula dikatakan bahwa pembelajaran adalah usaha sadar yang dilakukan oleh pendidik atau orang dewasa lainnya untuk membuat pebelajar dapat belajar dan mencapai hasil belajar yang maksimal. (Yamin, 2013:15)

Sebagaimana yang telah dijelaskan pada kurikulum (PAl) bahwa Pendidikan Agama Islam adalah upaya sadar dan terencana dalam menyiapkan peserta didik untuk mengenal, memahami, menghayati, mengimani, bertakwa, berakhla mulia, mengamalkan ajaran agama Islam dari sumber utamanya kitab suci al-Qur'an dan al-Hadits melalui kegiatan bimbingan, pengajaran, latihan, serta penggunaan pengalaman, disertai dengan tuntunan untuk menghormati penganut agama lain dalam hubungannya dengan kerukunan antarumat beragama dalam masyarakat hingga terwujud kesatuan dan persatuan bangsa. (Majid, 2012: 11)

Pendidikan Agama Islam memiliki tujuan atau arah sebagai mata pelajaran atau mata kuliah yang bersifat mendidikkan agama Islam yaitu berupa materi-materi yang sudah ada lalu kemudian disampaikan 
dan dipelajari untuk diamalkan. (Abdurrahman, 2012).

Sebagaimana dikatakan oleh Daradjat (dalam Majid, 2012: 12) bahwa Pendidikan Agama Islam (PAI) adalah suatu usaha untuk membina dan mengasuh peserta didik agar senantiasa dapat memahami ajaran Islam secara menyeluruh. Lalu menghayati tujuan, yang pada akhirnya dapat mengamalkan serta menjadikan Islam sebagai pandangan hidup.

Menurut GBPP Pendidikan Agama Islam (PAI) di sekolah umum, dijelaskan bahwa Agama Islam (PAI) adalah usaha sadar untuk menyiapkan siswa dalam meyakini, memahami, menghayati, dan mengamalkan agama Islam melalui kegiatan bimbingan, pengajaran, dan/atau latihan dengan memperhatikan tuntutan untuk menghormati agama lain dalam hubungan kerukunan antar umat beragama dalam masyarakat untuk mewujudkan persatuan nasional.

Sumber pembelajaran merupakan segala sesuatu yang dapat memberikan informasi atau penjelasan, berupa definisi, teori, konsep, dan penjelasan yang berkaitan dengan pembelajaran. (Nata, 2009: 295). Sumber pembelajaran dapat berupa manusia, material (bahan), lingkungan, alat dan perlengkapan (tool and equipment), aktivitas. Sumber pembelajaran sering disebut juga dengan sumber belajar, yang dimaksud dengan sumber belajar manusia adalah orang yang secara langsung menyampaikan pesanpesan pengajaran tanpa menggunakan alat lain sebagai perantara.

Pada umumnya guru melakukan berbagai kegiatan di kelas dalam rangka mencapai tujuan pembelajaran. Berbagai strategi pembelajaran dilakukan untuk mendorong terjadinya proses pembelajaran. Hal yang penting yang harus dikuasai oleh guru adalah mampu menyediakan bahan ajar bahan pembelajran yang dapat dipelajrai sendiri oleh peserta didik. Artinya bahan tersebut mampu memberikan kesempatan kepada peserta didik untuk mengukur perilaku belajarnya tanpa ada campur tangan guru atau temennya, yang dimaksud dengan bahan ajar adalah seperangkat materi yang disusun secara sistematis baik tertulis maupun tidak, sehingga tercipta lingkungan atau suasana yang memungkinkan peserta didik belajar. (LPTK IAIN Sunan Ampel Surabaya 2012)

Bahan ajar merupakan seperangkat materi/substansi pembelajaran (teaching material) yang disusun secara sistematis, menampilkan sosok utuh dari kompetensi yang akan dikuasai peserta didik dalam kegiatan pembelajaran (Depdiknas, 2008a). Dengan bahan ajar memungkinkan peserta didik dapat mempelajari suatu kompetensi atau KD secara runtut dan sistematis, sehingga secara akumulatif mampu menguasai semua kompetensi secara utuh dan terpadu. Menurut National Center for Vocational Education Research Ltd/National Center for Competency Based Training, bahan ajar adalah segala bentuk bahan yang digunakan untuk membantu pendidik/instruktur dalam melaksanakan kegiatan belajar mengajar di kelas. Bahan yang dimaksud bisa berupa bahan tertulis maupun bahan tidak tertulis (Warpala, 2011).

Jadi, dapat disampaikan bahwa bahan ajar adalah merupakan seperangkat materi yang disusun secara sistematis sehingga tercipta lingkungan/suasana yang memungkinkan peserta didik untuk belajar.

Berdasarkan teknologi yang digunakan, bahan ajar dapat dikelompokkan menjadi empat kategori, yaitu: 1) bahan cetak (printed) seperti antara lain handout, buku, modul, brosur, leaflet, wallchart, model/maket; 2) bahan ajar dengar (audio) seperti kaset, radio, piringan hitam, dan compact disk audio; 3) bahan ajar pandang dengar (audio visual) seperti video compact disk, film; 4) bahan ajar multimedia interaktif (interactive teaching material) seperti CAI (Computer Assisted Instruction), compact disk (CD) multimedia pembelajaran interaktif, dan bahan ajar berbasis web (web based learning materials).

Modul adalah sebuah buku yang ditulis dengan tujuan agar peserta didik dapat belajar secara mandiri tanpa atau bimbingan pembelajar. Pembelajaran dengan modul memungkinkan peserta didik yang memiliki kecepatan tinggi dengan 
alam belajar akan lebih cepat menguasai kompetensi dasar. (Sumantri, 2015: 333). Modul merupakan salah satu bentuk bahan ajar yang dikemas secara utuh dan sistematis, didalamnya memuat seperangkat pengalaman belajar yang terencana dan didesain untuk membantu peserta didik menguasai tujuan belajar yang sepesifik (Daryanto, 2013: 9).

Berdasarkan latar belakang tersebut, maka peneliti memusatkan perhatian untuk menjawab 5 (lima) pertanyaan penelitian. (1) Bagaimanakah proses pengembangan modul Pendidikan Agama Islam berbasis multikultural? (2) Bagaimanakah tanggapan ahli terhadap draft pengembangan modul Pendidikan Agama Islam berbasis multikultural? (3) Bagaimanakah tanggapan peserta didik dalam uji perorangan dan uji kelompok kecil terhadap draft pengembangan modul Pendidikan Agama Islam berbasis multikultural? (4) Bagaimanakah tanggapan pendidik dan siswa dalam uji lapangan terhadap draft pengembangan modul Pendidikan Agama Islam berbasis multikultural?

Bagaimanakah efektifitas produk penelitian, yang dapat diukur dengan melihat perbedaan antara skor-skor pretest dan posttest yang dicapai peserta didik dalam pembelajaran dengan menggunakan bahan ajar Pendidikan Agama Islam berbasis multikultural?

\section{METODE}

Penelitian ini merupakan jenis penelitian pengembangan Research and Development dengan menggunakan model pengembangan Dick and Carrey yakni suatu penelitian yang digunakan untuk pengembangan produk, dan menguji keefektifan produk, penelitian ini bertujuan mengembangkan produk berdasarkan uji coba kemudian direvisi sampai menghasilkan produk yang layak dipakai 9berupa modul yang memerlukan prosudur tertententu yang sesuai dengan sasaran yang akan dicapai, struktur isi pembelajaran yang jelas dan memenuhi kreteria yang berlaku bagi pengembangan pembelajaran. Model pengembangan Dick and Carrey dipilih karena model ini menguraikan langkah-langkah pengembangan lebih terinci dari pada model pengembangan yang lain. Disisi lain model ini dianggap cocok pada penelitian yang kami kembangkan berupa modul pendidikan agama islam berbasis multikultural di SMA Negeri 2 Amlapura pada siswa kelas $X$ disemester 2.

Ada 10 tahapan proses yang dilakukan mulai dari awal pengembangan sampai pada produk sebagai hasil pengembangan, yaitu: (1) Menganalisis kebutuhan untuk mengidentifikasi tujuan (intructional goal );

(2) Menganalisis pembelajaran;

Menganalisis pembelajaran dan konteknya;

(4) Menuliskan tujuan untuk kerja; (5) Mengembangkan instrumen penilaian; (6) Mengembangkan strategi pembelajaran; (7) Mengembangkan dan memilih bahan pembelajaran; (8) Merancang dan melaksanakan evaluasi formatif; (9) Merevisi pembelajaran;

Dalam penelitian ini peneliti merangkum dan memodifikasi model pengembangan dick dan carey kedalam empat tahap yaitu: (1) tahap mendefinisikan kebutuhan (2) tahap mendesain produk (3) tahap pengembangan dan evalusi (4) tahap desiminasi produk akhir. Ujincoba dilakukan beberapa tahapan dimulai dari ahli media dan ahli isi dalam bidang pendidikan Agama Islam agar menghasilkan modul yang siap diuji cobakan. Produk yang telah siap diuji cobakan perlu adanya validasi produk. Untuk mendapatkan validasi produk maka penulis menggunakan angket, kemudian dilakukan uji coba perorangan diambil 3 orang siswa yang terdiri dari satu orang siswa yang memiliki kemampuan tinggi, sedang dan siswa yang memiliki prestasi yang rendah pada mata pelajaran pendidikan Agama Islam, uji coba kelompok kecil terdiri dari 9 orang siwa yang terdiri dari tiga orang yang memiliki kemampuan tinggi, tiga orang yanmg memiliki kemampuan sedang dan tiga orang yang memiliki kemampuan rendah, penentuan hasil belajar dilihat dari hasil belajar pendidikan Agama Islam pada semester ganjil. dan uji coba lapangan terdiri dari uji siswa dan guru. Uji coba lapangan pada siswa yang beragama islam melibatkan satu kelas dengan jumlah siswa 13 orang 
pada siswa dikelas sepuluh SMA Negeri 2 Ampura sedangkan uji lapangan pendidik diminta salah seorang guru pendidikan agama Islam di SMA Negeri 1 Amlapura.

Teknik analisis data kuantitatif digunakan untuk mengolah data yang diperoleh dari angket dalam bentuk deskriptif persentase. Metode analisis deskriptif kualitatif ialah suatu cara pengolahan data yang dilakukan dengan jalan menyusun secara sistematis dalam bentuk angka-angka atau persentas,mengenai onjek yang diteliti, sehingga diperoleh kesimpulan umum. (Agung, 2010:61). Rumus yang digunakan untuk menghitung persentase masingmasing responden sebagai berikut.

$$
\begin{aligned}
& \text { Persentase }=\frac{\sum \text { Skor }}{S M I} \times 100 \% \\
& \text { Keterangan: } \\
& \begin{array}{ll}
\sum \text { Skor } \quad=\text { Jumlah skor } \\
\text { SMI } \quad=\text { Skor maksimal ideal }
\end{array}
\end{aligned}
$$

Selanjutnya persentase keseluruhan subjek dihitung menggunakan rumus berikut:

$$
\begin{aligned}
& \text { Persentase rata-rata }=\frac{F}{N} \\
& \text { Keterangan: } \\
& \mathrm{F}=\text { jumlah persentase keseluruhan } \\
& \text { subyek } \\
& \mathrm{N}=\text { banyak subjek }
\end{aligned}
$$

Hipotesis penelitian dengan uji-t (paired samples $t$-test) dibantu dengan menggunakan perangkat lunak SPSS 16 dengan ketentuan sebagai berikut: 1) $t$ hitung $>\mathrm{t}$ maka tabel $\mathrm{H}_{0}$ ditolak, dan 2) jika $\mathrm{t}$ hitung $<\mathrm{t}$ tabel maka $\mathrm{H}_{0}$ diterima. Untuk memakai keefektifan peningkatan hasil belajar, maka skor rata-rata posttest akan dicocokkan dengan konversi kualifikasi hasil belajar SMA Negeri 2 Amlapura.

Sebelum dilakukan pengujian hipotesis penelitian, terlebih dahulu dilakukan uji normalitas dengan menggunakan perangkat lunak SPSS 16.0. Uji Normality Kolmogorov-Smirnov. Uji data adalah hal yang lazim dilakukan sebelum sebuah metode stistik. Uji normalitas merupakan salah satu bagian dari uji prasyarat analisis data atau biasa disebut asumsi klasik. Bertujuan untuk mengetahui apakah distribusi sebuah data mengikuti atau mendekati distribusi normal, yakni distribusi data yang mempunyai pola seperti distribusi normal. Untuk memastikan apakah data yang kita miliki mengikuti distribusi normal, kita dapat lihat pada kolom sig. Untuk kedua uji, jika sig atau P lebih dari 0,05 maka dapat disimpulkan hipotesis nol/gagal/ditolak, yang berarti data yang diuji memiliki distribusi yang tidak berbeda dari data yang normal. Atau dengan kata lain data yang diuji memiliki distribusi normal.

\section{HASIL DAN PEMBAHASAN}

Proses pengembangan modul pendidikan agama islam berbasis multikultural dengan tahapan-tahapan pengembangan model Dick dan Carey. Tahapan pertama menganalisis kebutuhan untuk mengidentifikasi tujuan kedua menganalisis pembelajaran ketiga menganalisis pembelajaran dan konteknya keempat menuliskan tujuan kelima instrumen penilaian keenam strategi pembelajaran ketujuh memilih bahan pembelajaran kedelapan evaluasi formatif dan sembilan Merevisi pembelajaran.

Proses yang dilakukan dalam pengembangan modul pendidikan Agama Islam berbasis multikultural adalah menentukan mata pelajaran yang menjadi objek pengembangan. Mata pelajaran yang dijadikan pengembangan adalah mata pelajaran Pendidikan Agama Islam kelas $X$ semester genap. Selanjutnya adalah menganalisis kebutuhan sesuai dengan objek pengamatan yang telah ditentukan sebelumnya. Berdasarkan hasil wawancara lisan dengan peserta didik yang telah mempelajari mata pelajaran Pendidikan Agama Islam di kelas $X$, pembelajaran Pendidikan Agama Islam di SMA Negeri 2 Amlapura sampai saat ini masih menggunakan buku-buku atau bahan ajar cetak konvensional dan jumlahnya hanya sedikit tidak cukup dengan jumlah siswa. Pendidik hanya menggunakan sebuah buku sebagai satu-satunya bahan ajar. Bahan ajar cetak tersebut hanya berisi ringkasan materi, contoh soal dan latihan-latihan soal dalam pembelajaran Pendidikan Agama Islam. Strategi pengorganisasian dan 
penyampaian isi di dalam bahan ajar tersebut tidak terstruktur dengan baikdan belum sesuai dengan karakteristik, lingkungan sosial, geografis, budaya dan lain-lain dari siswa yang ada. Materi yang disajikan di dalam bahan ajar cetak tersebut banyak yang bersifat abstrak dan rumit sehingga siswa enggan untuk membacanya apalagi mempelajarinya. Khusus untuk bahan ajar yang berupa bahan cetak seperti modul yang memang benar-benar sesuai dengan karakteristik modul belum banyak digunakan.

Hasil review peneliti terhadap bahan ajar yang digunakan pendidik dalam kegiatan pembelajaran Pendidikan Agama Islam di SMA Negeri 2 Amlapura di dapatkan bahwa, materi ajar yang tersaji di dalam bahan ajar tersebut jarang dikaitkan dengan objek-objek atau kejadian-kejadian aktual di dunia nyata yang akrab dengan peserta didik. Materi ajar yang disajikan hanya berupa konsep, sekumpulan fakta-fakta contoh soal,dan latihan soal. Permasalahan-permasalahan yang disajikan mengandung objekdan kejadian yang di idealkan yang tidak memiliki kaitan dengan realitas peserta didik. Modul Pendidikan Agama Islam berbasis multikultural bertujuan untuk melengkapi pembelajaran Pendidikan Agama Islam, khususnya dalam pembelajaran Pendidikan Agama Islam kelas $X$. Untuk itu, guru dan siswa sangat membutuhkan saebuah modul pembelajaran yang lebih memotivasi siswa untuk belajar dan memudahkan guru untuk memfasilitasi siswa untuk belajar.

Setelah analisis kebutuhan dapat dilanjutkan pada proses pengembangan draft modul Pendidikan Agama Islam berbasis multikultural. Pada proses pengembangan draft modul Pendidikan Agama Islam ini dibagi menjadi tiga bagian yaitu analisis kondisi pembelajaran, langkah pengembangan, dan langkah pengukuran hasil belajar. Analisiskondisi pembelajaran terdiri dari (1) analisis tujuan dan karakteristik mata pelajaran, (2) analisis sumber belajar, (3) analisis karakteristik pebelajar, dan (4) menetapkan kompetensi dasar dan indikator hasil belajar.
Dalam mereview modul pendidikan Agama Islam berbasis multikultural melibatkan ahli isi, ahli desain dan ahli media yang yang sesuai dengan bidangnya pada program study Teknologi Pendidikan di Universitas Pendidikan Ganessha. Dari hasil review masing-masing ahli menyatakan bahwa modul pendidikan agama islam berbasis multikultural yang dikembangkan sudah sesuai. Ahli isi memberikan saran pada kalimat stop zina diganti menjadi hindari zina, ayat-ayat alquran dilengkapi dengan terjemahan yang lengkap sedangkan ahli media memberikan saran sebaiknya penulisan huruf menggunakan ukuran 12 sebagai teks pokok. Berdasarkan hasil uji ahli isi dan ahli media dapat dikatakan bahwa modul pendidikan agama islam berbasis multikultural yang dikembangkan layak untuk digunakan akan tetapi suatu saat nanti bisa diadakan perbaikan atau dievaluasi.

Review yang dilakukan oleh ahli desain pada modul pendidikan agama islam berbasis multikultural adalah seorang dosen yang ahli pada teknologi pembelajaran pada program pasca sarjana Universitas Pendidikan Ganesha.Pedoman yang digunakan untuk memberikan makna dan pengambailan

Hasil review dari guru pendidikan Agama secara umum memberikan tanggapan bahwa modul pendidikan Agama Islam berbasis multikultural sudah baik, dengan hasil menunjukan sebesar $90,61 \%$ pada kualifikasi sangat baik. Berdasarkan hasil uji lapangan menunjukan bahwa modul pendidikan Agama Islam berbasis multikultural sudah layak digunakan.

Uji coba lapangan pada siswa yang beragama islam melibatkan satu kelas dengan jumlah siswa 13 orang pada siswa dikelas sepuluh SMA Negeri 2 Ampura. Untuk mengambil data uji coba lapangan penulis menggunakan angket uji coba lapangan untuk siswa. Dengan hasil uji coba lapangan yang lampirkan pada lampiran

Hasil uji coba lapangan kepada siswa yang beragama islam menunjukkan bahwa 8 orang responden atau sebesar $61,54 \%$ memberikan tanggapan sangat baik dimana 
modul layak untuk digunakan, namun masih diperlukan perbaikan dalam penulisan kata. Dan 5 orang responden atau sebesar $38,46 \%$ memberikan tanggapan baik dan masih diperlukan perbaikan dalam penulisan kata dan penambahan atau perubahan gambar tampilan yang lebih menarik sehingga siswa dapat lebih tertarik dengan modul ini. Berdasarkan data yang dapat penulis rangkum dari keseluruhan prosentase subyek sebesar $88,07 \%$ dengan kategori baik, dapat disimpulkan bahwa modul pendidikan agama Islam berbasis multikultural dapat dikembangkan dan layak untuk digunakan, namun tidak menutup kemungkinan untuk diadakan revisi (perbaikan) kembali

\section{PENUTUP}

Berdasarkan hasil analisis data dan pembahasan pada penelitian pengembangan ini, maka dapat diambil simpulan sebagai berikut.1)draf modul pendidikan Agama Islam berbasis multikultural dikembamngkan sesuia dengan desain pengembangan modul yang diadaftasi dengan model Dick dan Carey yang diawali Menganalisis kebutuhan untuk mengidentifikasi tujuan dan diakhiri dengan hasil Pretest dan Posttests.2) tanggapan ahli isi dan ahli media tentang modul pendidikan Agama Islam berbasis multikultural bahwa modul yang dikembangkan sudah layak untuk digunakan dalam pembelajaran pendidikan Agama Islam.3)hasil uji perorangan kepada peserta didik dapat dirangkum bahwa modul pendidikan agama islam berbasis multikultural menghasilkan baik4) dalam uji kelompok kecil menghasilkan baik tentang modul pendidikan Agama Islam berbasismultikultural. 5) modul Pendidikan Agama Islam berbasis multikultural dalam uji lapangan (guru) menghasilkan baik dan layak untuk digunakan dalam pembelajaran. 6) rata-rata hasil nilai belajar peserta didik dalam menggunakan modul pendidikan Agama Islam berbasis multikultural terdapat perbedaan sebelum menggunakan modul. Ditinjau dari konversi hasil belajar siswa kelas X SMA negeri 2 Amlapura, nilai rata-rata posttest 94,462, dengan kualifikasi baik, nilai rata-rata menunjukan diatas nilai KKM mata pelajran pendidikan Agama Islam dengan KKM 80. Rata-rata nilai posttest menunjukan lebih besar dari nilai Pretest, maka hasil pembelajaran dengan menggunakan modul pendidikan Agama Islam berbasis multikultural bisa dikatakan meningkat.

Berdasarkan hasil penelitian, pembahasan dapat disimpulkan dan diajukan beberapa saran sebagai berikut. Penelitian pengembangan bahan ajar modul pendidikan Agama Islam berbasis multikultural menghasilkan bahan ajar cetak, diharapkan nanti untuk penelitian pengembangan selanjutnya berupa $\mathrm{E}$ Modul yaitu modul berbasis ICT yang dikombinasi dengan program android sehingga nantinya siswa akan lebih mudah belajar melalui tablet dan handphone yang sudah android, dengan harapan agar siswa bisa belajar modul pendidikan agama islam berbasis multikultural lebih optimal. selanjutnya diharapkan, penelitiannya tidak sebatas sampai hasil uji Pretest dan Posttest, namun penelitian pengembangan selanjutnya sampai pada uji kelompok yang menggunakan bahan ajar cetak konvensional dengan bahan ajar yang sudah dikombinasikan dengan modelmodel pembelajaran yang lain, atau pada modul yang sudah didampingi dengan $C D$ pembelajaran.

\section{DAFTAR RUJUKAN}

Direktorat Pendidikan Agama Islam Pada Sekolah,(2010). Panduan Model Kurikulum Pendidikan Agama Islam Berbasis Multikultural Sekolah Menengah Atas, (Jakarta: Direktorat Pendidikan Agama Islam Pada Sekolah Direktorat Jenderal Pendidikan Islam Departemen Agama

Daryanto (2013) Menyusun Modul, Malang: Gava Media

Majid, A. D. A. (2003). Pendidikan Agama Islam Berbasis Kompetens. Bandung: Remaja Rosda Karya. 
Suparmi. (2012). Pembelajaran Kooperatif Dalam Pendidikan Multikultural. Jurnal Pembangunan Pendidikan: Fondasi dan Aplikasi. 1(1). 108-118..

Sumantri, S. M. ( 2015) Strategi Pembelajaran.( Teori dan Praktik di Tingkat Pendidikan Dasar ) Jakarta: PT. Raja Grapindo Persada.

Yamin,M. (2013) Strategi dan Metode dalam Model pembelajran. Jambi: Referensi

Nata, A. (2009) Perspektif Islam Tentang Strategi belajar mengajar. Jakarta: Kencana Prenada Media Group.

Tegeh, IM.\& Kirna, I M. (2010) Metode Penelitian Pengembangan Pendidikan.Singaraja. Universitas Pendidikan Ganesha.

Warpala, I W. S. 2011. Pedoman dasar pengembangan bahan ajar cetak dan pemilihan media pembelajaran. Makalah disampaikan dalam Pelatihan pengembangan bahan ajar bagi pendidik-pendidik SD, SMP, SMA dan SMK se Propinsi Bali, pada tanggal 9 - 13 Mei 2011. 